Vytautas Dikcius,

Professor, Faculty of Economics, Vilnius University (Vilnius, Lithuania);

Indre Pikturniene

Associate Professor, Faculty of Economics, Vilnius University (Vilnius, Lithuania);

Vilmante Pakalniskiene,

Associate Professor, Faculty of Economics, Vilnius University (Vilnius, Lithuania);

Eleonora Seimiene,

Lecturer, Faculty of Economics, Vilnius University (Vilnius, Lithuania);

Monika Kavaliauske,

Lecturer, Faculty of Economics, Vilnius University (Vilnius, Lithuania);

James Reardon,

Professor, Faculty of Economics, Vilnius University (Vilnius, Lithuania)

\title{
THE IMPACT OF PARENTS' TECHNOLOGY READINESS AND THEIR SUSCEPTIBILITY TO INTERPERSONAL INFLUENCE ON ADOLESCENTS' PARTICIPATION IN PARENTAL DECISION MAKING TO PURCHASE TECHNOLOGICAL PRODUCTS ${ }^{1}$
}

Scholarly literature provides sufficient evidence on children's participation in parents' purchase decision depending on product type, decision-making stages, demographic profiles of parents and children, but a few studies have been carried out in terms of the influence of parental psychological characteristics. Current research fulfils the gap by providing evidence on how parents' technology readiness and their susceptibility to interpersonal influence predict adolescents' participation in parental purchase decision making with regard to technological products: products for family use and products for child's use. A survey of 345 parents with children aged from 12 to 18 years old was performed by a research company using the internet panel. The findings provide evidence that parental technology readiness is a strong predictor of child's participation into the family purchase decision making process. Parental susceptibility to interpersonal influence is a predictor of child's participation depending on the decision stage and type of product. Findings open the room for contributions about effects of other parental psychographics, on children's psychographics, and even on interaction among both for the better understanding of purchase decision in the family.

Keywords: child, purchase decision, consumer behaviour, technology readiness, susceptibility to interpersonal influence.

DOI: $10.21272 / \mathrm{mmi} .2017 .3-12$

Research problem. The issue of children's participation in parental purchase decision has been widely discussed through the recent decades. Although in-depth analyses suggest that the children's overall influence on parents might be exaggerated [15], evidence is strong to confirm their participation in various decision-making stages [25] with respect to different elements of the decision [19] or different types of products [14]. Even though some demographic characteristics of children and parents explained the level of children's participation in purchase decision, but impact of psychological characteristics of parents' was not included in previous researches.

Parental decisions to purchase technological products are related to high levels of uncertainty [12]. Due to the intergenerational influence [16], it could be expected that parents become submissive to the influence of adolescents when technological products are addressed and involve them into the purchase decision making more intensively. Thus, the parental level of susceptibility to interpersonal influence could be the factor which explains the level of adolescent influence in purchase decision making. Another characteristics of a decision maker, technology readiness, is a determinant of prejudice against

\footnotetext{
${ }^{1}$ This research was funded by the project No. MIP-017/2015 from the Lithuanian Research Council.
} 
technological products [27] and their purchase. Since parents differ in their technology readiness level, as well as due to adolescents' high involvement into technological products, we might expect that parents' technology readiness could be a predictor for adolescent participation in parental decision making to purchase technological products.

The problem addressed in the current research is as follows: Do two psychological characteristics of parents' - technology readiness and susceptibility to interpersonal influence - have an impact on adolescent participation in family purchase decision making with regard to technological products? The aim of the research was to test the impact of parents' technology readiness and susceptibility to interpersonal influence on adolescent participation in parental decision on purchasing technological products. The importance of these factors will be verified on two types of products - the product for family use and the one for adolescent's use, since the level of adolescent involvement is likely to depend on these two types of products [14].

Literature Review and Hypotheses. Parents' and children's interaction before the final purchase decision making is well supported through the theories of consumer socialisation $[9,16,20]$, influencemaking powers [21], family type [28] and parental style [1]. The adolescent's participation in parents' purchase decision making is related to demographic characteristics of children as well. Children are reported to be more engaged in decision making with growing age [10,20], since they are recognised as possessing knowledge and time resources, bringing valuable information from peers [17] and media [36]. Gender of children can be important for their participation as well [13]. Children's participation in parents' decision making differs depending on products. Children are more involved in purchase of convenience products when compared to shopping goods [3, 4]. Child's involvement is the lowest when the product is purchased for parents, of middle-level when the product is for family use, and the highest when the product is targeted at a child [14].

It is common to distinguish at least four stages of decision making (initiation, information search, alternative evaluation and decision). However, a number of authors indicated that there is difference of children's impact on parents' decision only between initiation stage and all other stages [19, 20, 35]. These authors stated that the children had the biggest impact during initiation of the process of decision making, while children's impact during other stages - information search, alternative evaluation and decision - was significantly lower and equal among the last three stages. In addition, one of the most popular constructs that assesses children's contribution into parental purchase decisions delineates only two sufficiently discriminating stages: initiation and information search/decision stage [3, 4].

When mutual decisions are addressed, psychological characteristics of parties become important determinants of the final outcome. In terms of the purchase of technological products, technology readiness becomes a very important predictor for the perceived usefulness and for the perceived ease of use in TAM model [26]. Technology readiness, as such, encompasses several dimensions in relation to technologies: innovativeness, optimism towards technologies, discomfort and insecurity [32]. While the first two dimensions are positive and naturally bound with technology readiness, the latter two hinder technology adoption and are more likely to be seen as barriers rather than innate traits of technology readiness [33]. We hypothesize that the extent to which parents will involve children in the decision making on the purchase of technological products will differ depending on two positive aspects of parents' technology readiness (two negative aspects are not addressed due to difficulties in measurement [33]). A parent who is more optimistic towards innovation will not only be more open to an adolescent's suggestion to consider a new technological product, but also will be more inclined to address the information suggested by an adolescent in the initiation and decision making stages.

H1: Parents' optimism in technology positively predicts child's participation in (A) initiation stage and (B) information search/decision stage of the purchase of technological products.

On the other hand, if parents are highly innovative, they should be the major initiators and experts of technology-related products. Innovators themselves are opinion leaders in the field [34] and look neither for confirmation, nor for information provided by others (adolescent in this context) before their purchase 
В. Дікцюс, І. Піктумене, В. Пакалніскене, Е. Сеймене, М. Каваляуске, Дж. Рирдон. Вплив технологічної готовності батьків та їхня схильність до міжособистісного впливу на участь підлітків в батьківських рішеннях придбання технологічних продуктів

decision. Following the Theory of Resources [6], the more resources (knowledge, innovativeness) parents hold themselves, the less children would be involved into the purchase decision. On the contrary, if children are seen as more resourceful, their involvement into the two decision-making stages will be higher. The hypothesis that summarises our considerations is as follows:

H2. Parents' innovativeness with regard to technology negatively predicts child participation into (A) initiation stage and $(B)$ information search/decision stage of the purchase of technological products.

Susceptibility to interpersonal influence is a concept that allows capturing the individual differences in submission to personal influence of others. As suggested by Bearden, Netemeyer, and Teel [2], people are affected by informational and normative influence. On the one hand, while purchasing products, they might be looking and affected by the information they gain from others, on the other hand, they predict the opinions and behavioural outcomes of others before and after making the purchase, since each purchase might be judged in line with the compatibility to the established norms/standards. Parents who are susceptible to interpersonal influence, should more easily involve adolescents into purchase decision making. Since nowadays adolescents are acknowledged as grown-ups in earlier years [17], their involvement into purchase decision making should be higher in case of highly informational influence susceptible parents. Similarly, susceptibility to normative influence means that parents are looking for the confirmation/impression provided by others, including adolescents whom they might acknowledge as contemporary, knowledgeable in technologies, or simply emotionally important to them. To sum up, we hypothesise the following:

H3: Parents' susceptibility to the informational influence positively predicts child participation in $(A)$ initiation stage and (B) information search/decision stage of the purchase of technological products.

$\mathrm{H} 4$ : Parents' susceptibility to normative influence positively predicts child participation in $(A)$ initiation stage and $(B)$ information search/decision stage of the purchase of technological products.

Since technological products are addressed, we assume that boys are slightly more engaged in technologies in comparison to girls [39], thus the level of their participation in both stages of the purchase decision making would be higher. When adults are addressed, females are reported to have a lower intention to apply technologies [31] and to be more inclined to consider the perceived easiness to use technology, whereas males would focus on the perceived usefulness [40]. Overall, this suggests that mothers would be more likely to engage knowledgeable others (adolescents, in this context) into the purchase of technological products, than fathers. Thus, gender of parents and children would be controlling variables in the hypothesised relationships.

Research methodology. Optimism towards technology and innovativeness were measured as proposed by Parasuraman [32], who included these domains into technology readiness index. However, the measure of optimism was slightly subtracted following the example of Elliott, Meng, and Hall [18]. Thus, latent variables of optimism and innovativeness were operationalised by 6 and 7 items respectively. Susceptibility to interpersonal influence was measured fully following Bearden et al. [2]: 8 items for normative, 4 for informational influence. Each statement of the independent variables was measured using a 7 point scale (1-strongly disagree, 7-strongly agree). A dependent variable, child's participation in parental purchase decision, was measured using Beatty and Talpade's instrument [3], which allows capturing child's contribution during the initiation stage (4 items) and information search/decision stage ( 5 items). The statements were followed by a 7 point scale, where 1 meant "Child did not contribute at all", 7 meant "Child made full contribution". The level to which the child will be involved in purchase decision could be dependent on whether the product is for child as opposed to the family use [14]. Therefore, the hypotheses will be tested on two technological products - a TV set for family use and a mobile phone for an adolescent's use.

The survey was performed in Lithuania by a research company using the internet panel. The respondents were parents with children aged from 12 to 18. If a respondent had several children aged 
within the appropriate range, they had to provide answers only about the older child. Approximately, there are 30000 of children born annually in Lithuania. We estimate that there should be from 100000 to 130000 families with adolescents from 12 to 18 years in Lithuania (some families have several children; also there is possible children loss due to high emigration and deaths). Thus, it was aimed for 384 respondents (parents) within the sample, which would assure 95 percent of confidence level. However, only 345 subjects who completed questionnaires correctly were included in the analysis. The distribution of the questionnaires according to the gender of an adolescent was even, with the mean of age of 15 years old. With regard to the respondents' gender, the proportion was $49 \%$ of men, $51 \%$ of women, with average age of 43 years old. All demographic data of adolescents and respondents are presented in Table 1.

Table 1 -The demographic data of respondents

\begin{tabular}{|l|l|l|l|l|l|}
\hline $\begin{array}{c}\text { Gender of } \\
\text { adolescents }\end{array}$ & Percentage & \multicolumn{1}{|c|}{$\begin{array}{c}\text { Gender of } \\
\text { parents }\end{array}$} & Percentage & \multicolumn{1}{|c|}{ Education of parents } & Percentage \\
\hline Girl & 49.9 & Women & 52.2 & University & 53.6 \\
\hline Boy & 50.1 & Man & 47.8 & College, high school & 45.8 \\
\hline & & & & Unfinished high school & 0.6 \\
\hline & & & & & \\
\hline $\begin{array}{l}\text { Number of } \\
\text { children }\end{array}$ & Percentage & Marital status & Percentage & $\begin{array}{l}\text { Incomes of a parent per } \\
\text { month }\end{array}$ & \\
\hline 1 & 25.7 & Married & 82.2 & Less than 300 EUR & 28.8 \\
\hline 2 & 51.8 & Divorced & 14.5 & 300-500 EUR & 36.2 \\
\hline 3 and more & 22.5 & Other & 3.3 & More than 500 EUR & 35.0 \\
\hline
\end{tabular}

Findings. To examine relations between susceptibility, technological readiness, and initiation, decision, we tested structural regression model with Mplus 6.0 [30]. For all these analyses, we used full information maximum likelihood (FIML) because we used raw data as the input file for the program and some of the data were missing. We tested two models: one for purchasing a mobile phone and another one for purchasing a TV. In both models model there were several latent variables: informational susceptibility (4 variables), normative susceptibility (8 variables), technological readiness optimism (6 variables), technological readiness innovativeness (7 variables), and child's influence in initiation stage (4 variables) and decision (5 variables) stages. In both models informational susceptibility, normative susceptibility, technological readiness optimism, technological readiness innovativeness together with child's and his or her parent's gender predicted child influence in initiation and decision stages for buying.

Both models tested in this study were evaluated using several goodness-of-fit indices: CFI (Comparative Fit Index [7]); RMSEA (Root Mean Square Error of Approximation; [8]); and TLI (TuckerLewis Index; [38]). CFI and TLI values greater than 0.90 represent an adequate fit to the data [7]; values greater than 0.95 suggest a good model fit [24]. RMSEA values less than 0.08 represent reasonable errors of approximation; values less than 0.05 indicate a close model fit with the data [8]. Both tested models had an adequate fit (see Table 2).

Table 2 - The goodness-of-fit indices for both models

\begin{tabular}{|l|l|l|}
\hline \multirow{2}{*}{ Criteria } & \multicolumn{1}{|c|}{ Model for a mobile phone } & \multicolumn{1}{c|}{ Model for a TV set } \\
\cline { 2 - 3 } & \multicolumn{1}{|c|}{ Value } & \multicolumn{1}{c|}{ Value } \\
\hline$X^{2}(554)$ & 1256.06 & 1237.79 \\
\hline$p$ & $<0.001$ & $<0.001$ \\
\hline CFI & 0.91 & 0.92 \\
\hline TLI & 0.90 & 0.91 \\
\hline RMSEA & 0.06 & 0.06 \\
\hline
\end{tabular}


В. Дікцюс, І. Піктумене, В. Пакалніскене, Е. Сеймене, М. Каваляуске, Дж. Рирдон. Вплив технологічної готовності батьків та їхня схильність до міжособистісного впливу на участь підлітків в батьківських рішеннях придбання технологічних продуктів

All the latent variables had sufficient factor loadings. Informational susceptibility to interpersonal influence factor loadings ranged from 0.66 to 0.83 in the model with mobile phone and from 0.66 to 0.82 in the model with TV, normative susceptibility to interpersonal influence - from 0.65 to 0.91 in the model with mobile and from 0.65 to 0.90 in the model with TV, technological readiness optimism - from 0.53 to 0.82 in the model with mobile and from 0.52 to 0.82 in the model with TV, technological readiness innovativeness from 0.62 to 0.84 in the model with mobile and from 0.62 to 0.83 in the model with TV, initiation stage from 0.69 to 0.90 in the model with mobile and from 0.82 to 0.92 in the model with TV, and information search/decision stage - from 0.68 to 0.86 in the model with mobile and from 0.83 to 0.92 in the model with TV. The findings that disclose the relationships among the variables are summarized in Figure 1.

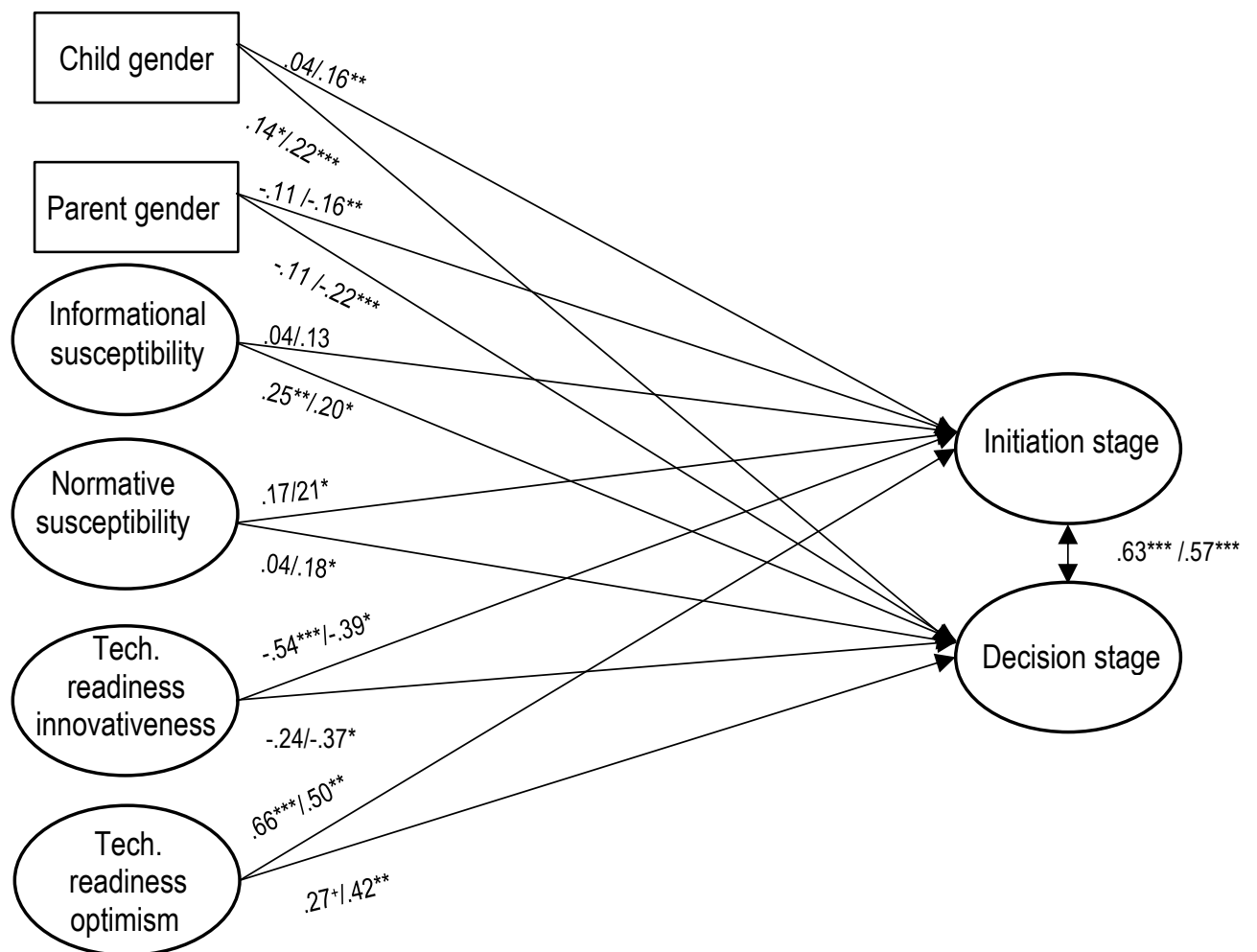

Note. ${ }^{* *} p<0.001 ;{ }^{* *} p<0.01 ;{ }^{*} p<0.05,+p<0.1$. First coefficient is for buying a mobile phone for the child and second coefficient is for buying a TV for the whole family model

\section{Figure 1 - Relationship of parents' technology readiness and susceptibility to interpersonal influence with adolescents' participation in family purchase decision making}

Both the dimensions of parents' technology readiness showed the influence on adolescents' participation. Their participation is positively predicted by - optimism towards technologies in initiation stage of purchasing both products - a product for use of the whole family (EstTV $=0.50$ ) and a product for the individual use of an adolescent (EstMP $=0.66)$. Moreover, the same dimension of technology readiness (optimism) had positive relation with adolescents' participation in information search/decision stage for buying a product for use of the whole family (EstTV $=0.42$ ) and a product for the individual use of an adolescent (EstMB $=0.27$ ). Thus, $\mathrm{H} 1$ is confirmed in both stages (with a certain caution in the case 
of the product for child use) and we can conclude that parents' optimism in technology positively predicts child's participation in a family purchase decision making.

In the same line, adolescents' participation is negatively predicted by innovativeness as technology readiness dimension: in the initiation stage of purchasing a product for the individual use of an adolescent (EstMP $=-0.54)$ and for a product for use of the whole family (EstTV = -0.39). However, innovativeness with regard to technologies had a negative influence on information search/decision stage only in the case of purchasing a product for use of the whole family (EstTV $=-0.37$ ), while the influence of purchasing a product for the individual use of an adolescent was not significant (Est $=-0.24$, $\mathrm{p}=0.142$ ). $\mathrm{H} 2$ is confirmed in both stages (with an exception of a mobile phone in information search/decision stage), which let us to make a conclusion that parents' innovativeness with regard to technology negatively predicts child participation in a family purchase decision making. These results prove the importance of parental personal characteristic, that is, technology readiness, for adolescents' involvement in parents' decision to purchase technological products.

Susceptibility to interpersonal influence has an impact on adolescent participation in parents' decision making as well. Informational susceptibility to interpersonal influence positively predicts adolescents' participation in information search/decision stage for both products (EstTV $=0.20$ and EstMP $=0.25$ ), but has no influence on initiation stage. Since susceptibility to interpersonal influence addresses person's inclination to take into account information from other sources, the findings are in line with theory: this personal dimensions starts playing a role during the stage that is mostly related to information collection and evaluation. On the other hand, initiation stage might be more related to actual needs of family or adolescent, but not the information as such. Thus, we can confirm just the B part of $\mathrm{H} 3$.

Normative susceptibility to interpersonal influence predicts adolescents' participation in initiation stage and in information search/decision stage with regard to a family product (EstlS $=0.21$, EstDS= 0.18 ), but has no influence in the case of a product for adolescent's use. Thus, we prove $A$ and $B$ parts of $\mathrm{H} 4$ only for family products. These findings are also in line with expectations: it appears that for the family products susceptibility to personal pressure plays more influence in starting considering the product at all, when a product is for family (group) use, and requires certain intergroup interactions while making a decision. That pressure transcends to information/decision making stage, where a group, most likely, still makes a common decision. When a product is for individual use of adolescent, personal characteristic related to reaction to intergroup norms loses power.

All established relationships are depicted in figure 1.

In both models the children's and parents' gender had an effect on adolescents' participation in parents' decision making to purchase products. Being a boy could increase adolescents' participation in information search/decision stage for both technological products: a product for the individual use of an adolescent $(E s t M P=0.14)$ and a product for use of the whole family $(E s t T V=0.22)$. In addition, boys have higher participation in initiation stage in purchasing a product for use of the whole family (EstTV= $0.16)$. Such results are similar to previous authors $[13,39]$ and confirm assumption that boys are more engaged parental decision to buy technological products.

Parents' gender would also have an effect on adolescents' participation. Being a male tends to decrease adolescents' participation in both stages - in the initiation stage (EstTV $=-0.16)$ and in the information search/decision stage (EstTV $=-0.22$ ) with regard to a product for use of the whole family. However parents' gender had no relation with adolescents' participation in both stages of parental decision to buy a product for the individual use of an adolescent (the initiation stage EstMB $=-0.11$, the information search/decision stage EstMB $=-0.11$. .

Conclusions and Limitations. Overall, the results prove that personal characteristics of parents are determinants to what extent children will be involved into parental purchase decision. Findings open the room for contributions about effects of other parental psychographics, on children's psychographics, and even on interaction among both for the better understanding of purchase decision in the family. The findings confirm that parents' technology readiness is a predictor of adolescents' participation in parents' 
В. Дікцюс, І. Піктумене, В. Пакалніскене, Е. Сеймене, М. Каваляуске, Дж. Рирдон. Вплив технологічної готовності батьків та їхня схильність до міжособистісного впливу на участь підлітків в батьківських рішеннях придбання технологічних продуктів

decision to purchase technological products. Two positive domains of technology readiness, innovativeness and optimism, predict in opposite directions. Parents' optimism is a positive predictor for adolescents' participation in the stage of initiation of both the products, for the family and the child's use. Parents listen more to the suggestions, talk more to their adolescents about technological products when they are in general optimistic about innovation. However, in the decision making stage, optimism remains a predictor only for a family use product. Parents' innovativeness, as negative predictor, is also strong in the initiation stage: resourceful (innovative) parents involve adolescents far less. Parents' innovativeness as a negative predictor also holds for the decision stage for a family product. However, both the domains lose the predictive power in cases where the product is targeted at the adolescent. Obviously, when a technological product is meant for a child himself, parents' technology readiness characteristics are not important, and powers shift towards the adolescent.

Parents' susceptibility to informational influence plays nil roles in the product initiation stage. Interestingly enough, parents' susceptibility to informational influence becomes a predictor of adolescents' involvement in the decision making stage: most likely adolescents are seen as a source of information. Susceptibility to normative influence plays a role only in the purchase of a family product. Obviously, a family product puts more pressure on reaching the consensus and good interpersonal relationships within the family, thus an adolescent is more involved in both stages of purchase decision.

In line with the findings of previous studies, we found that boys are more involved in the purchase decision making than girls for technological products. Moreover, mothers are more likely to involve children into the purchase of a technological product if compared to fathers when the product is for family usage.

The two inhibiting domains of technology readiness, discomfort and insecurity were not addressed; however, we presume that by nature they would be negatively correlating with the positive domains and hardly adding value to the evidence in the parents' technology readiness impact on adolescents' participation in the parents' purchase of technological products. Only two products were chosen in each category, as the analysis of other products belonging to these categories would increase the credibility of the results. If TV set or mobile phone were not recently purchased, the respondents were asked to respond about the imaginary situations without sufficient recent purchase experience; however, both situations are realistic and easy to respond about in the family context.

Managerial implications. Based on this study, marketing managers can have more assurance in identifying roles of decision making within families, when technological products are addressed. It is obvious that if parents are highly technologically savvy, they do not involve their children into the purchase. Although this study does not address the proportion of population of technologically savvy parents, it could be assumed that it is not substantial. For other parents, as appears, adolescents are influential, especially mothers. On the other hand, if parents believe technological products make lives better (optimism towards innovation), they keep involving children more often. Again, although proportions of populations for optimism parameter are not clear, many people are positive in regard to them, suggesting that adolescents would be involved in the decision. Thus, adolescents, especially boys, are vital target for various information within their limits of knowledge in deciding which product to purchase. Other findings of study provide more clear guidelines what should be communicational pressures during various decision making stages. Apparently, if product for a child is purchased (mobile phone), informational susceptibility is nil during initiation stage, and starts playing a role only during decision making stage. Since nowadays internet tracking allows assuming, at which stage consumers are a lot of information from various sources on comparable characteristics should be provided for parents close to the final decision. However, if TV (family product) is purchased, normative influence starts playing a role in all stages. Thus, communication could create a normative pressure (such as "it is time to update TV set, everybody already has accepted the novelty, etc."), and involve an adolescent as a pressure maker.

1. Bao, Y., Fern, E.F., \& Sheng, S. (2007). Parental style and adolescent influence in family consumption decisions. Journal of Business Research, 60(7), 672-680.

2. Bearden, W.O., Netemeyer R.G., \& Teel, J.E. (1989). Measurement of consumer susceptibility to interpersonal influence. 
Journal of Consumer Research, 15(4), 473-481.

3. Beatty, S.E., \& Talpade, S. (1994). Adolescent influence in family decision making: a replication with extension. Journal of Consumer Research, 21, 332-341.

4. Belch, M.A., Krentler, K.A., \& Flurry, L.A. (2005). Teen internet mavens: influence in family decision making. Journal of Business Research, 58, 569-575.

5. Bentler, P.M. (1990). Comparative fit indexes in structural models. Psychological Bulletin, 107, 238-246.

6. Blood Jr, R.O., \& Wolfe, D.M. (1960). Husbands and wives: the dynamics of family living. New York: Free Press.

7. Bentler, P.M., \& Bonnett, D.G. (1980). Significance tests and goodness-of-fit in the analysis of covariance structures. Psychological Bulletin, 88, 588-606.

8. Browne, M.W., \& Cudeck, R. (1993). Alternative ways of assessing model fit. In: K.A. Bollen, \& J.S. Long (eds.), Testing structural equation models (pp. 136-162). London: Sage.

9. Buijzen, M., \& Valkenburg, P.M. (2008). Observing Purchase-Related Parent-Child Communication in Retail Environments: A Developmental and Socialization Perspective. Human Communication Research, 34(1), 50-69.

10. Chavda, H., Haley, M., \& Dunn, C. (2005). Adolescents' influence on family decision-making. Young Consumers, 6(3), 68-78.

11. Clark, R.A., \& Goldsmith, R.E. (2006). Global innovativeness and consumer susceptibility to interpersonal influence. Journal of Marketing Theory and Practice, 14(4), 275-285.

12. Claudy, M.C., Garcia, R. \& O'Driscoll, A. (2015) Consumer resistance to innovation-a behavioural reasoning perspective. Journal of the Academy Marking Science, 43(4), 528-544

13. Dauphin, A., Lahga, E., Fortin, B., \& Lacroix, G. (2011). Are children decision-makers within the household? The Economic Journal, 121(553), 871-903.

14. Dikcius, V., Armenakyan, A., Urbonavicius, S., Jonyniene, G., \& Gineikiene, J. (2014). The influence of children on family purchasing in Lithuania and Azerbaijan. Organizations \& Markets in Emerging Economies, 5, 79-96.

15. Dikcius, V., Armenakyan, A., Pikturniene, I., Seimiene, E., Pakalniskiene, V., Kavaliauske, M., Katkuvienè, K., \& Reardon, J. (2016). Children's influence on their parents' purchase decision: systematic analysis of researches between 1985-2014. In I. Simberova, O. Zizlavsky, \& F. Milichovsky (ed.), Proceedings of International Scientific Conference Economics and Management (pp.182-189), May 19-20, Brno, Czech Republic.

16. Ekstrom, K.M. (2007). Parental consumer learning or 'keeping up with the children'. Journal of Consumer Behaviour, 6(4), 203-217.

17. El Aoud, N.H., \& Neeley, S.M. (2008). Teenager-peer interaction and its contribution to a family purchase decision: the mediating role of enduring product involvement. International Journal of Consumer Studies, 32(3), 242-252.

18. Elliott, K., Meng, G., \& Hall, M. (2012). The influence of technology readiness on the evaluation of self-service technology attributes and resulting attitude toward technology usage. Services Marketing Quarterly, 33, 311-329.

19. Foxman, E.R., Tansuhaj, P.S., \& Ekstrom, K.M. (1989a). Family members' perceptions of adolescents' influence in family decision. Journal of Consumer Research, 15, 482-491.

20. Foxman, E.R., Tansuhaj, P.S., \& Ekstrom, K.M. (1989b). Adolescents' influence in family purchase decisions: a socialization perspective. Journal of Business Research, 18, 159-172.

21. Flurry, L.A., \& Burns, A.C. (2005). Children's influence in purchase decisions: a social power theory approach. Journal of Business Research, 58(5), 593-601.

22. Goldsmith, R.E., Freiden, J.B., \& Eastman, J.K. (1995). The generality/specificity issue in consumer innovativeness research. Technovation, 15(10), 601-612.

23. Grossbart, S., Carlson, L., \& Walsh, A. (1991). Consumer socialization and frequency of shopping with children. Journal of the Academy of Marketing Science, 19(3), 155-163.

24. Hu, L., \& Bentler, P.M. (1998). Fit indices in covariance structure modelling: Sensitivity to underparameterized model misspecification. Psychological Bulletin, 3, 424- 453.

25. Lee, C.K.C., \& Beatty, S.E. (2002). Family structure and influence in family decision making. Journal of Consumer Marketing, 19(1), 24-41.

26. Lin, C.-H., Shih, H.-Y., \& Sher, P. J. (2007). Integrating technology readiness into technology acceptance: the TRAM model. Psychology \& Marketing, 24, 641-657.

27. Lin, J.S.C., \& Chang, H. C. (2011). The role of technology readiness in self-service technology acceptance. Managing Service Quality: An International Journal, 21(4), 424-444.

28. Mangleburg, T.F., Grewal, D., \& Bristol, T. (1999). Family type, family authority relations, and adolescents' purchase influence. Advances in Consumer Research, 26, 379-384.

29. Marshall, R., \& Reday, P.A. (2007). Internet-enabled youth and power in family decisions. Young Consumers, 8, 177-183.

30. Muthén, L.K., \& Muthén, B.O. (2006). Mplus users guide. Los Angeles: Muthén and Muthén.

31. Padilla-Meléndez, A., del Aguila-Obra, A.R., \& Garrido-Moreno, A. (2013) Perceived playfulness, gender differences and technology acceptance model in a blended learning scenario. Computers \& Education, 63, 306-317.

32. Parasuraman, A. (2000). Technology readiness index (TRI): a multiple-item scale to measure readiness to embrace new technology. Journal of Service Research, 2(4), 307-320.

33. Parasuraman, A., \& Colby, C.L. (2015). An updated and streamlined technology readiness index TRI 2.0. Journal of service research, 18(1), 59-74.

34. Rogers, E. (1963). What are innovators like? Theory Into Practice, 2(5), 252-256

35. Shoham, A., \& Dalakas, V. (2005). He said, she said ... they said: parents' and children's assessment of children's influence on family consumption decisions. Journal of Consumer Marketing, 22, 152-160 
В. Дікцюс, І. Піктумене, В. Пакалніскене, Е. Сеймене, М. Каваляуске, Дж. Рирдон. Вплив технологічної готовності батьків та їхня схильність до міжособистісного впливу на участь підлітків в батьківських рішеннях придбання технологічних продуктів

36. Tinson, J., \& Nancarrow, C. (2007). 'GROw'ing up: tweenagers' involvement in family decision making. Journal of Consumer Marketing, 24(3), 160-170.

37. Roehrich G. (2004). Consumer innovativeness Concepts and Measurements. Journal of business research 57, 671-677

38. Tucker, L.R., \& Lewis, C. (1973). The reliability coefficients for maximum likelihood factor analysis. Psychometrica, 3, 1-10.

39. Vekiri, I., \& Chronaki, A. (2008). Gender issues in technology use: perceived social support, computer self-efficacy and value beliefs, and computer use beyond school. Computers \& education, 51(3), 1392-1404.

40. Venkatesh, V., \& Morris, M.G. (2000). Why don't men ever stop to ask for directions? Gender, social influence, and their role in technology acceptance and usage behavior. MIS Quarterly, 24(1), 115-139.

В. Дікцюс, професор, Факультет економіки, Вільнюський університет (м. Вільнюс, Литва)

I. Піктумене, доцент, Факультет економіки, Вільнюський університет (м. Вільнюс, Литва);

В. Пакалніскене, доцент, Факультет економіки, Вільнюський університет (м. Вільнюс, Литва);

E. Сеймене, викладач, Факультет економіки, Вільнюський університет (м. Вільнюс, Литва);

М. Каваляуске, викладач, Факультет економіки, Вільнюський університет (м. Вільнюс, Литва);

Дж. Рирдон, профессор, Факультет економіки, Вільнюський університет (м. Вільнюс, Литва)

Вплив технологічної готовності батьків та їхня схильність до міжособистісного впливу на участь підлітків в батьківських рішеннях придбання технологічних продуктів

Наукова література дає достатні докази участі дітей в ухваленні рішення батьків про покупку залежно від типу продукту, етапів ухвалення рішень, демограсрічних профілів батьків і дітей, але тільки кілька досліджень були проведені з точки зору впливу батьківських психологічних характеристик. Здійснене дослідження усуне цю прогалину, надаючи докази того, як технологічна готовність батьків і їхня схильність до міжособистісних впливів пророкують участь підлітків у батьківських рішеннях про покупку технологічних продуктів: продуктів для всієї родини і товарів для дітей. Дослідження 345 батьків з дітьми у віці від 12 до 18 років було проведено дослідницькою компанією, що використовує інтернет-панель. Отримані дані свідчать про те, що технологічна готовність батьків є сильним предиктором участі дитини в процесі ухвалення рішень про покупку. Батьківська сприйнятлливість до міжособистісного впливу є предиктором участі дитини залежно від стадії ухвалення рішення і типу продукту. Висновки відкривають простір для вкладів стосовно есфектів інший батьківської психографії, дитячої психографії навіть взаємодії між ними як для кращого розуміння рішення про покупку в сім'ї.

Ключові слова: діти, рішення про покупку, поведінка споживачів, технологічна готовність, схильність до міжособистісних впливів.

В. Дикцюс, профессор, Факультет экономики, Вильнюсский университет (г. Вильнюс, Литва)

И. Пиктумене, доцент, Факультет экономики, Вильнюсский университет (г. Вильнюс, Литва);

В. Пакалнискене, доцент, Факультет экономики, Вильнюсский университет (г. Вильнюс, Литва);

Е. Сеймене, преподаватель, Факультет экономики, Вильнюсский университет (г. Вильнюс, Литва);

М. Каваляуске, преподаватель, Факультет экономики, Вильнюсский университет (г. Вильнюс, Литва);

Дж. Рирдон, профессор, Факультет экономики, Вильнюсский университет (г. Вильнюс, Литва)

Воздействие технологической готовности родителей и их склонность к межличностным влияниям на участие подростков в родительских решениях на приобретение технологических продуктов

Научная литература дает достаточнье доказательства участия детей в принятии решения родителей о покупке в зависимости от типа продукта, этапов принятия решений, демографических профрилей родителей и детей, но только несколько исследований были проведены с точки зрения влияния родительских психологических характеристик. Осуществленное исследование устранит этот пробел, представляя доказательства того, как технологическая готовность родителей и их склонность к межличностным влияниям предсказывают участие подростков в родительских решениях о покупке технологических продуктов: продуктов для всей семьи и товаров для детей. Исследование 345 родителей с детьми в возрасте от 12 до 18 лет было проведено исследовательской компанией, использующей интернет-панель. Полученные данные свидетельствуют о том, что технологическая готовность родителей является сильным предиктором участия ребенка в процессе принятия решений о покупке семьи. Родительская восприимчивость к межличностному влиянию является предиктором участия ребенка в зависимости от стадии принятия решения и типа продукта. Выводы открывают пространство для вкладов в отношении эфффектов другой родительской психографии, детской психографрии и даже взаимодействия между ними как для лучшего понимания решения о покупке в семье. Ключевые слова: дети, решение о покупке, поведение потребителей.

Ключевые слова: дети, решение о покупке, поведение потребителей, технологическая готовность, склонность к межличностным влияниям.

Отримано 12.04.2017 p. 